\title{
SAFETY OF OPERATION AND MAINTENANCE SYSTEMS OF AIRCRAFT FLEET
}

\section{BEZPIECZEŃSTWO SYSTEMÓW EKSPLOATACJI FLOTY STATKÓW POWIETRZNYCH}

\author{
Jerzy Lewitowicz ${ }^{1}$, Waldemar Gołębiowski ${ }^{2}$, Kamila Kustroń ${ }^{3}$
}

(1) Air Force Institute of Technology

Instytut Techniczny Wojsk Lotniczych

01-494 Warszawa ul. Księcia Janusza 6

(2) Polish Air Force Academy

Wyższa Szkoła Oficerska Sil Powietrznych

08-521 Dęblin, ul. Dywizjonu 303

(3) Warsaw University of Technology

Politechnika Warszawska

00-665 Warszawa, ul. Nowowiejska 24

E-mail: (1) jlewito@meilpwedupl (2) pigeon7@wp (3) klust@meilpwedupl

\begin{abstract}
The flight of on aircraft has been realzed I on operational subsystem. The operation of on aircraft and its safeability are determined for aircraft fleet the so-called flight safety. Aircraft operation and its safeability determine the flight safety of aircraft fleet. The flight safety can be modelled, condition diagnosed, put the procedures of genesis and prognosis. As the results of these activities the prevention treatments can be worked out. A aircraft safety, air system safety or air safety can be considered. Within the flight safety science.
\end{abstract}

Keywords: safety, maintenance, operation, exploatation, aircraft

Streszczenie. Lot SP realizuje się w eksploatacyjnym podsystemie zwanym podsystemem użytkowania SP. Użytkowanie SP i jego bezpieczność determinują dla floty statków powietrznych tzw. bezpieczeństwo lotów. Podlega ono modelowaniu, diagnozowaniu stanu bieżącego, genezowaniu i prognozowaniu, czego wynikiem są opracowywane przedsięwzięcia profilaktyczne. W nauce o bezpieczeństwie lotów wyróżnia się takie pojęcia, jak bezpieczeństwo SP, bezpieczeństwo systemu lotniczego, bezpieczeństwo powietrzne.

Slowa kluczowe: bezpieczeństwo, utrzymywanie (zdatności), eksploatacja, statki powietrzne 


\section{SAFETY OF OPERATION AND MAINTENANCE SYSTEMS OF AIRCRAFT FLEET}

\section{Introduction}

The system for operating a fleet of aircrafts has properties which can be divided into properties measured with SI units and properties "measured" in probability terms. These properties ensure the functioning of a system and result from the specificity of not only an individual aircraft but from operating a group (fleet) comprising very often different types of aircrafts as well. These properties determine the system specificity. Some properties of an operation system are more essential for a proper functioning of the system and for obtaining assumed targets and some less. A property called safety is one of basic properties of an operational system. This feature determines the aircraft mission safety, i.e. the flight safety.

\section{Safety and safeability of operating and maintenance systems}

When characterising the flight safety, its resistance to possible occurred dangerous situations is also taken into account. For aviation systems the concept of „safety” includes the following issues: safeability, flight safety, aviation safety and safety management. Transport systems and contained therein operation systems are regarded as human factor engineering ,man machine" where also the environmental impact with a very essential feature of possible averting - fending off - dangerous situations by an operator (human) are taken into account.

One distinguishes between two system safety statuses (from a descriptive approach): the status of safety unreliability (factor $Q_{\boldsymbol{B}}$ ) and the status of safety reliability (factor $R_{B}$ ) [1].

An aircraft (SP) has a property called a safeability [7]. The operation of every technical system, with an aircraft regarded as such, takes place in an environment of other systems and subsystems including a subsystem for maintaining the SP capability, a logistics subsystem and, finally, the air space surrounding it. This environment along with the aircraft safeability determines the aviation system safety denominated as the flight safety $[7,8]$. 


\section{Operating system safety factors}

One distinguishes basic and additional factors - coefficients. Basic coefficients describe essential features of the safety of an operational system. Among basic factors rate e.g. all probability characteristics of a random variable i.e. of a system operation time till its transient into the state of system unreliability as well as probability characteristics of unreliability, of availability, of system vulnerability etc.

The additional factors are the probability characteristics of dwelling time in individual safety states, probability characteristics describing transients between system safety-related states.

Basic factors characterize the safety of the entire system. Usually, additional factors deal only with some aspects of the system safety. Factors of this kind are used only to determine basic coefficients.

Apart from the safety unreliability factor $Q_{B}$ and the safety reliability factor $R_{B}$, another basic safety coefficients is also a transient (events) intensity factor $\lambda_{B}$ expressed as [1]:

$\lambda_{B}=\frac{\mathrm{d} Q_{B}(t)}{\mathrm{d}(t)} \cdot \frac{1}{1-Q_{B}}$

From (1) we can obtain the following form of the $R_{B}$ factor:

$R_{B}(t)=R_{B}\left(t_{0}\right) \exp \left[-\int_{0}^{t} \lambda_{B}(\tau) \mathrm{d} \tau\right]$

The leading function of the safety unreliability distribution $\Lambda_{B}$ and the expected value of the operation time till the moment of a system transition into a state of safety unreliability $\mathbf{E}\left(T_{B}\right)$ are the next two important safety coefficients:

$$
\begin{aligned}
& \Lambda_{B}(t)=\int_{0}^{t} \lambda_{B}(\tau) \mathrm{d} \tau \\
& \mathrm{E}\left(T_{B}\right)=\int_{0}^{\infty} R_{B}(\tau) \mathrm{d} \tau
\end{aligned}
$$

where: $T_{B}$ is a random variable of the system operation till its transition into a state of safety unreliability. 


\section{Operation system vulnerability}

The vulnerability expresses the probability of destroying a system or at least a change of its operation function [7]. The vulnerability is the impact of some disadvantageous events, which paralyses a system. This can be a:

- technical damage to a part of system;

- system operator's error;

- system management terror;

- impact of adverse environment conditions (e.g. birds, atmospheric discharge), enemy action;

- impact of adverse climate/weather conditions (e.g. fog affecting transport systems).

The measure of a system "paralysis" is the probability of its entering the zone of paralysing impact. Consequently the probability of paralysing is the system's vulnerability to being paralysed.

For a "paralysed" system there is still some time available $\left(T_{D}\right)$, during which a dangerous situation can be counteracted by many methods to avert a crash, failure or damage to a system.

\section{Flight safety}

The flight safety science uses such concepts as the SP safety, aircraft system safety, and aviation (air) safety. The aircraft safety determines an aircraft capability under complex operation conditions to stay within a risk range nor exceeding a criterion value.

The aircraft system safety is a set of properties of a system comprising aircrafts, ground control measures and aviation control measures, aircraft crews, ground personnel and ground maintenance personnel taking care of aircraft proper technical condition and preventing the arising of emergency situations, protecting passengers and offering rescue measures in case of equipment breakdowns, crew errors or ground personnel errors as well as in the cases of unwanted external impacts.

The aircraft safety manifests itself by dangerous situations resulting in various effects occurred in aircraft accidents due to occurrence of unwanted events. The science of aviation safety and in particular the science of flight safety concerning the system C(P)-SP-O: man (pilot, crew)-aircraftenvironment researches all these phenomena, concepts and properties $[2,3$, 7].

The problem of flight safety and aviation - air - safety is studied within a set of aircraft flight safety (BLSL) and a single aircraft flight safety (BLSP). 
The SP safety depends also on its design. It can be called a technical safety. The flight safety is dependent both on the design safety and on the design of other parts of a system, i.e. on the human (people) and environment.

The aviation - air - safety is understood as a system of knowledge the main purpose of which is to discover laws and regularities and working out rules and ways of action in order to ensure safe performance of flights by aircrafts when taking into account adverse impacts from the environment.

The safety level for systems of operating aircraft fleets is analysed in a continuous manner. The safety level and its trends are expressed with the aid of various measures: e.g. risk, factors, event probability using for it analytical methods, e.g. theory of probability, geometric methods, neural networks. According to relevant current requirements the most usual measure of the flight safety is defined by different coefficients and by the accident rate function $F W[4,5,7,8]$.

One of the main flight safety coefficients is the coefficient of grave accidents $W W c$ defined as a ratio: number of accidents $W c$ to the flying time $N$ (in flight hours or as a standard time of 100000 flight time in air forces or to the number of passengers $L$ for civil aviation (standard number of 1 million of passengers)

The accident rate function $(F W)$ is a real function $W(t)$ which for every real value of $t$ determines the probability $P$ of an aviation system (defined by the number of aircrafts) capable of opertaion expressed by a selcted property (number of aircarfts capable of flying) at the $t_{0}$ time, where after a $\Delta \tau$ time this capability will be decreased by a value proportional to the cahnge of the accident rate function $\Delta W$.

The $W(t)$ function depends on the properties of operation of the system under discussion characterised by features $(\mathrm{k})$, on its operation conditions and requiremetns (s), which in order for the system to be accepeted as fit must be met. If the accident rate is measured with the accident factor, e.g. heavy acccidents $W W c$, when aircarfts are lost and this $W W c$ is multipled by a factor (average losses) of the weight $p$ and by the planned flying time $N p$. (standard: $10^{5}$ flight hours) this function can be expressed as:

$$
W(t)=\mathrm{P}\{p, N p, W W c(\tau ; k, s) ; 0<\tau \leq t, W W c(\mathrm{o} ; k, s)\}
$$

where: $\tau$ - prediction time interval; $W W c$ - function of the heavy accident factor; $N p$ - number of planned flying time over $\tau$ time; $p$ - coefficient of average losses of aircrafts or crews; $k$-aviation system characterics; $s-$ conditions for operating an aviation system and requirements for it . 
The accident rate function in its $W(t)$ form and short-term changes $D W W c$ make it possible to prognosticate changes of the $W W c$ coefficient and losses of aircrafts and crews. The applied calculation method provided the basis to predict a certain growth (local maximum) of the $W W c$ factor over $2005-$ 2007 and $2005-2006$ and further predicts this coefficient to rise after 2010 for Polish Air Forces (Fig. 1). As the $W W c$ over 2003 - 2007 fairly well agrees with the theoretical predictions it demonstrates that the number and character of factors causing unwanted events did not change substantially.

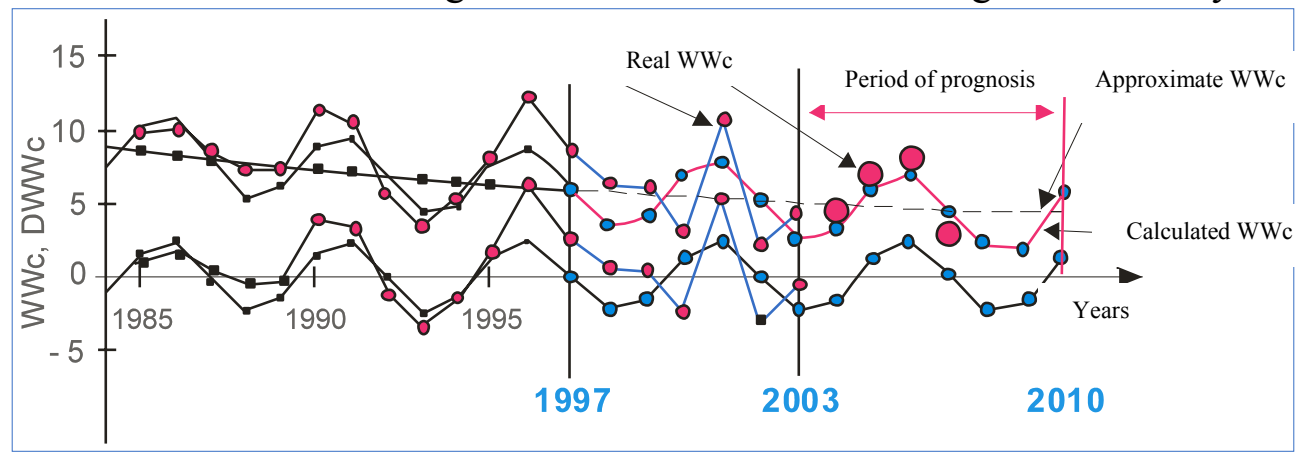

Fig. 1. $W W c$ and $D W W c$ changing over $1984-2010$

The analysis of flight safety coefficients and the function of accident rate are used to work out adequate prophylactic recommendations $[6,7]$.

\section{Bibliography}

1. Jaźwinski J., Ważynska-Fiok K.: Bezpieczeństwo systemów. PWN, Warsaw 1993.

2. Gracberg C.: The role of human factors in improving aviation safety. Aero Boeing, 08, October, 1999.

3. Kersterson B.: Human factors and human reliability. Proc. Maintenance, Reliability and Cost Analysis Seminar, Long Beach (USA) 2000.

4. Lewitowicz J.: Diagnozowanie, genezowanie $i$ prognozowanie wskaźników bezpieczeństwa. Zagadnienia Eksploatacji Maszyn, Z. 2 (122), V. 35, 2000.

5. Lewitowicz J.: Genezowanie zdarzeń eksploatacyjnych. Diagnostyka, No 7 (39) 2006. 
6. Lewitowicz J.: Nauka o profilaktyce $w$ kształceniu pilotów i inżynierów eksploatacji statków powietrznych. Journal of Aeronautical Integra, No $1 / 2007$.

7. Lewitowicz J.: Podstawy eksploatacji statków powietrznych. T. 3. Systemy eksploatacji statków powietrznych. Wyd. ITWL, Warsaw 2006.

8. Lewitowicz J. i inni: Podstawy eksploatacji statków powietrznych. T. 4. Badanie eksploatacyjne statków powietrznych. Wyd. ITWL, Warsaw 2007.

9. Smalko Z.: Relations between safety and security in technical systems. International Journal of KONBIN,1(3), 2007. 


\section{BEZPIECZEŃSTWO SYSTEMÓW EKSPLOATACJI FLOTY STATKÓW POWIETRZNYCH}

\section{Wstęp}

System eksploatujący flotę statków powietrznych posiada cechy, które można podzielić na własności i właściwości. Zapewniają one działanie systemu, a wynikają ze specyfiki eksploatacji nie tylko pojedynczego statku powietrznego, ale także eksploatacji grupy (floty), często różnorodnych, typów statków powietrznych. Charakteryzują one równocześnie jego specyfikę systemową. Wśród właściwości systemu eksploatacji są bardziej i mniej istotne dla sprawnego jego funkcjonowania $\mathrm{i}$ otrzymywania zakładanych efektów. Do podstawowych właściwości systemu eksploatacji zalicza się właściwość zwana bezpiecznością. To ona determinuje bezpieczeństwo realizacji misji przez statki powietrzne zwane bezpieczeństwem lotów.

\section{Bezpieczeństwo i bezpieczność systemów eksploatacji}

Charakteryzując pojęcie bezpieczeństwa systemu, uwzględnia się także jego odporność na powstawanie sytuacji niebezpiecznych. Dla lotniczych systemów pojęcie „bezpieczeństwo” zawiera następujące pojęcia: bezpieczność, bezpieczeństwo lotów, bezpieczeństwo powietrzne i zarządzanie bezpieczeństwem.

Bezpieczność to właściwość gwarantująca integralność struktury systemu. Jest właściwością opisującą bezpieczeństwo działania [9].

Systemy transportowe i zawarte w nich systemy eksploatacji traktowane sa jako układy antropotechniczne typu „człowiek - maszyna” i wraz z wpływem środowiska $\mathrm{z}$ bardzo istotną cechą: możliwości likwidowania („odparowania”) sytuacji niebezpiecznych przez operatora (człowieka).

Rozróżnia się dwa stany bezpieczeństwa systemów (w ujęciu opisowym): stan zawodności bezpieczeństwa (wskaźnik $Q_{B}$ ) i stan niezawodności bezpieczeństwa (wskaźnik $R_{B}$ ) [1].

Statek powietrzny (SP) posiada właściwość zwaną bezpiecznością [7]. Działanie każdego systemu technicznego, a takim jest statek powietrzny, odbywa się $\mathrm{w}$ otoczeniu innych systemów i podsystemów, w tym: podsystemu utrzymywania zdatności SP, logistycznego i wreszcie otaczającej go przestrzeni powietrznej. To otoczenie, łącznie 
z bezpiecznością statku powietrznego, stanowi o bezpieczeństwie systemu lotniczego, które określa się pojęciem bezpieczeństwa lotów [7, 8].

\section{Wskaźniki bezpieczeństwa systemu eksploatacji}

Wyróżnia się wskaźniki podstawowe i pomocnicze (dodatkowe).

Wskaźniki podstawowe opisują istotne cechy bezpieczeństwa systemu eksploatacji. Zalicza się do nich np. wszystkie charakterystyki probabilistyczne zmiennej losowej, którą jest czas funkcjonowania systemu do chwili jego przejścia do stanu zawodności bezpieczeństwa, a także charakterystyki probabilistyczne zawodności, dyspozycyjności, porażalności systemu itp.

Wskaźnikami pomocniczymi są charakterystyki probabilistyczne czasu przebywania $\mathrm{w}$ poszczególnych stanach bezpieczeństwa, charakterystyki probabilistyczne opisujące przejścia między stanami bezpieczeństwowymi systemu itp.

Wskaźniki podstawowe charakteryzują bezpieczeństwo całego systemu. Wskaźniki pomocnicze zazwyczaj ujmują tylko niektóre aspekty bezpieczeństwa systemu. Wskaźniki tego typu są wykorzystywane do wyznaczania wskaźników podstawowych.

Do podstawowych wskaźników bezpieczeństwa, obok wskaźnika zawodności bezpieczeństwa $Q_{B}$ i niezawodności bezpieczeństwa $R_{B}$, zalicza się wskaźnik intensywności przejść (zdarzeń) zawodności bezpieczeństwa $\lambda_{B}$ wyrażony jako [1]:

$\lambda_{B}=\frac{\mathrm{d} Q_{B}(t)}{\mathrm{d}(t)} \cdot \frac{1}{1-Q_{B}}$

Ze wzoru (1) można uzyskać następującą postać wskaźnika $R_{B}$ :

$R_{B}(t)=R_{B}\left(t_{0}\right) \exp \left[-\int_{0}^{t} \lambda_{B}(\tau) \mathrm{d} \tau\right]$

Kolejne dwa ważne wskaźniki bezpieczeństwa to funkcja wiodąca rozkładu zawodności bezpieczeństwa $\Lambda_{B}$ i wartość oczekiwana czasu eksploatacji systemu do chwili jego przejścia do stanu zawodności bezpieczeństwa $\mathbf{E}\left(T_{B}\right)$ :

$\Lambda_{B}(t)=\int_{0}^{t} \lambda_{B}(\tau) \mathrm{d} \tau$ 


$$
\mathrm{E}\left(T_{B}\right)=\int_{0}^{\infty} R_{B}(\tau) \mathrm{d} \tau
$$

gdzie: $T_{B}$ jest zmienną losową czasu funkcjonowania systemu do chwili jego przejścia do stanu zawodności bezpieczeństwa.

\section{Porażalność systemu eksploatacji}

Porażalność wyraża prawdopodobieństwo zniszczenia systemu lub co najmniej zmiany jego funkcji działania [7]. Porażalność jest to oddziaływanie na system pewnych niekorzystnych zdarzeń doprowadzających do porażenia systemu. Porażeniem systemu może być:

- uszkodzenie technicznej części systemu;

- błąd operatora systemu;

- błąd w zarządzaniu systemem;

- oddziaływanie niekorzystnych warunków środowiska (np. ptaki dla samolotu, wyładowania atmosferyczne), oddziaływanie nieprzyjaciela;

- oddziaływanie niekorzystnych warunków klimatycznych (np. mgła dla systemów transportowych).

Miara porażenia systemu jest prawdopodobieństwo jego wejścia w strefę oddziaływania porażenia. A prawdopodobieństwo jego porażenia jest miarą jego wrażliwości na porażenie.

W systemie porażonym można jeszcze dysponować pewnym czasem $\left(T_{D}\right)$, w którym istnieje możliwość przeciwdziałania sytuacji niebezpiecznej różnymi metodami, co ma nie dopuścić do stanu katastrofy, awarii, czy uszkodzenia systemu.

\section{Bezpieczeństwo lotów}

W nauce o bezpieczeństwie lotów wyróżnia się takie pojęcia, jak bezpieczeństwo SP, bezpieczeństwo systemu lotniczego, bezpieczeństwo powietrzne.

Bezpieczeństwo statku powietrznego wyznacza jego zdolność, w złożonych warunkach eksploatacji (użytkowania), do pozostawania w stanie ryzyka nie większego od wartości kryterialnej.

Bezpieczeństwem systemu lotniczego nazywa się zbiór cech systemu, w skład którego wchodzą: statki powietrzne, naziemne środki sterowania i nawigacji lotniczej oraz kierowania ruchem lotniczym, załogi statków powietrznych, naziemny personel obsługujący i utrzymujący zdatność SP, zapobiegający powstawaniu sytuacji awaryjnych, zabezpieczający ludzi 
uczestniczących $\mathrm{w}$ locie przed ewentualnymi szkodami oraz zapewniający im ratunek w przypadkach uszkodzeń sprzętu, błędów załogi lub służb naziemnych, a także w przypadkach niepożądanych oddziaływań zewnętrznych.

Bezpieczeństwo statku powietrznego ujawnia się poprzez sytuacje niebezpieczne, wywołujące różne skutki powstałe w wypadkach lotniczych, które powstają $\mathrm{w}$ wyniku zaistnienia zdarzeń niepożądanych. Badaniem wszystkich tych zjawisk, pojęć, właściwości zajmuje się nauka o bezpieczeństwie a w lotnictwie, w szczególności nauka o bezpieczeństwie lotów odnosząca się do systemu C(P)-SP-O: Człowiek(pilot, załoga)-Statek Powietrzny-Otoczenie $[2,3,7]$.

Problem bezpieczeństwa lotów i bezpieczeństwa powietrznego rozpatruje się w układzie bezpieczeństwa lotów statków powietrznych - systemu lotniczego (BLSL) i pojedynczego statku powietrznego (BLSP). Bezpieczeństwo SP zależy także od własności jego konstrukcji. Można powiedzieć, że jest to bezpieczeństwo techniczne. Bezpieczeństwo lotów zależy tak od bezpieczeństwa konstrukcji, jak i od pozostałych członów systemu, to jest człowieka (ludzi) i otoczenia.

Bezpieczeństwo powietrzne rozumie się jako system wiedzy, którego głównym celem jest odkrywanie praw i prawidłowości oraz opracowywanie zasad i sposobów postępowania w celu bezpiecznego wykonywania lotów przez statki powietrzne $\mathrm{z}$ uwzględnieniem występujących warunków niesprzyjających, wywoływanych przez otoczenie.

Poziom bezpieczeństwa lotów w systemach eksploatacji floty statków powietrznych analizuje się w sposób ciagły. Poziom bezpieczeństwa i jego trend wyraża się za pomocą różnych miar na przykład: ryzyka, wskaźników, prawdopodobieństwa zdarzeń stosując różne metody analityczne na przykład: rachunek prawdopodobieństwa, metody geometryczne, sieci neuronowych. Zgodnie z obowiązującymi, współczesnymi wymaganiami najczęściej używaną miarę bezpieczeństwa lotów definiuje się poprzez wskaźniki o różnej postaci i funkcję wypadkowości $F W[4,5,7,8]$.

Do podstawowych wskaźników bezpieczeństwa lotów należy wskaźnik wypadków ciężkich $W W c$, który definiuje się jako stosunek liczby wypadków $W c$ do nalotu $N$ (w godzinach nalotu i znormalizowany do 100000 godzin nalotu w lotnictwie wojskowym) lub do liczby pasażerów $L$ w lotnictwie cywilnym (znormalizowany do jednego miliona pasażerów). 
Funkcja wypadkowości (FW) jest to funkcja rzeczywista $W(t)$ określajaca dla każdej rzeczywistej wartości $t$ prawdopodobieństwo $P$ systemu lotniczego (definiowanego liczbq statków powietrznych) posiadajacego zdolność do działania mierzonq wybranq cechq (liczbq zdolnych do lotów $S P) w$ chwili $t_{\mathrm{o}}$, która zmniejszy tę zdolność po czasie $\Delta \tau$ o wartość proporcjonalnq do zmiany funkcji wypadkowości $\Delta W$.

Funkcja $W(t)$ zależy od właściwości działania rozpatrywanego systemu o cechach $(k)$, warunków jego funkcjonowania oraz wymagań $(s)$, których spełnienia żąda się w celu uznania systemu za zdatny. Jeżeli wypadkowość zmierzy się wskaźnikiem wypadkowości, na przykład wypadków ciężkich $W W c$, w których traci się statki powietrzne i pomnoży się go przez współczynnik (średnich strat) wagi $p$ oraz planowany nalot $N p$ (znormalizowany do $10^{5}$ godz. lotu) to funkcję $W(t)$ można zapisać następująco:

$$
W(t)=\mathrm{P}\{p, N p, W W c(\tau ; k, s) ; 0<\tau \leq t, W W c(\mathrm{o} ; k, s)\}
$$

gdzie: $\tau$ - przedział czasu predykcji; $W W c$ - funkcja wskaźnika wypadków ciężkich; $N p$ - liczba planowanych godzin nalotu w czasie $\tau ; p-$ współczynnik średnich strat statków powietrznych lub załóg; $k$ - cechy systemu lotniczego; $s$ - warunki funkcjonowania i wymagania systemu lotniczego.

Funkcja wypadkowości w postaci W(t) i krótkookresowe zmiany DWWc umożliwiają prognozowanie zmian - wahań wskaźnika WWc i strat statków powietrznych oraz załóg. Zastosowana metoda obliczeń dała podstawę do przewidywań pewnego wzrostu (lokalne maksimum) wskaźnika WWc w 2005 - 2007 i 2005 - 2006 oraz przewiduje wzrost tego wskaźnika po 2010 roku w lotnictwie wojskowym RP. (rys. 1). Dobra zgodność wskaźników WWc w latach 2003 - 2007 z przewidywaniami teorii wskazuje na to, że liczba i charakter czynników powodujących zdarzenia niepożądane nie uległa zasadniczej zmianie. 


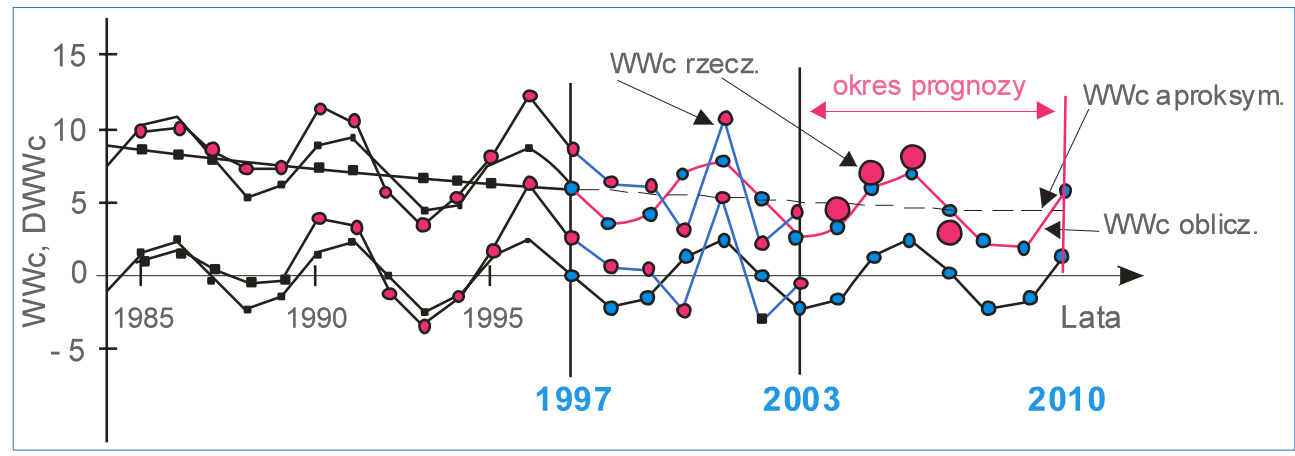

Rys. 1. Zmiana wskaźnika $W W c$ i $D W W c$ w latach $1984-2010$

Analiza wskaźników bezpieczeństwa lotów i funkcji wypadkowości służy opracowywaniu odpowiednich zaleceń profilaktycznych $[6,7]$.

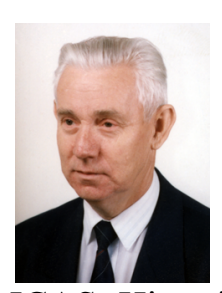

Prof. Jerzy Lewitowicz, PhD Eng., born in 1933 in Hrubieszów, holds the position of the tenured professor at the Instytut Techniczny Wojsk Lotniczych (Air Force Institute of Technology). The main lines of work comprise: advances in the most recent military technologies, in particular aeronautical ones; the aircraft engineering as well as the operational-use/maintenance of airplanes and helicopters, with special attention paid to the diagnostics. A member of the international aeronautical organizations: AIAA, ICAS. His scientific output comprises more than 250 publications. A co-author of eight books and 27 inventions. He holds the rank of Brigadier General (Ret).

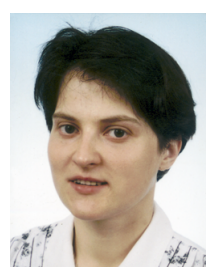

Kamila Kustroń, PhD Eng., is a lecturer/teaching assistant at the Department of Airplanes and Helicopters of the Warsaw University of Technology. Her scientific output comprises eleven papers presented at scientific conferences worldwide. The papers offer the Author's considerations involving structural issues and those of aircraft maintenance. The main areas of her work include aircraft ageing processes and fatigue of structural materials that find applications in aviation.

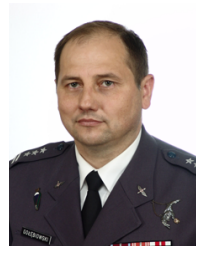

Col. Pilot Waldemar Golębiowski, MSc Eng., heads the Training Division at Wyższa Szkoła Oficerska Sił Powietrznych (Polish Air Force Academy) in Dęblin. Master rated pilot. Certified flight instructor and experimental test pilot. Areas of scientific interests: training systems for different aircraft types, aeronautical equipment/air armament testing, aircraft reliability and safety. Participant of international exercises to train air forces of NATO member countries. 
